\title{
New Trend for Using the Reduced Graphene Oxide as Effective and Eco-friendly Nematicide
}

\author{
REHAB YASSIN GAREEB ${ }^{1}$, MOHAMED SALAH ELNOUBY², MOAUYED AZIZ HASAN ${ }^{3}$, SIMONA TICU (COTORCEA) ${ }^{4}$, \\ AMORIN POPA ${ }^{5 *}$, SIMONA BUNGAU ${ }^{5 *}$, ELSAYED ELSAYED HAFEZ ${ }^{1}$ \\ ${ }^{1}$ Arid Lands Cultivation Research Institute (ALCRI), City of Scientific Research and Technological Applications, Borg El-Arab, \\ 21934, Alexandria, Egypt \\ ${ }^{2}$ Advanced Technology and New Materials Research Institute, City of Scientific Research and Technology Applications (SRTA- \\ CITY), New Borg El-Arab City, 21934, Alexandria, Egypt \\ ${ }^{3}$ College of Engineering, Gulf University, Sanad 743, Bahrain \\ 4Politehnica University of Bucharest, Faculty of Applied Chemistry and Materials Science, 1-7 Gh. P. Polizu Str., 011061, Bucharest, \\ Romania \\ EUniversity of Oradea, Faculty of Medicine and Pharmacy, 10, 1 Decembrie Sq., 410073, Oradea, Romania
}

Reduced graphene oxide ( $r$-GO) was synthesized chemically and it was characterized using Scanning Electron Microscope (SEM), Transmission Electron Microscope (TEM) and X-Ray Diffraction (XRD). The results revealed that the product $r-G O$ is nano-sheets with non-smooth surface; the size of the obtained nano-sheets ranged from 20 to $100 \mathrm{~nm}$. The well characterized nano-sheets were subjected to cytotoxicity test; results demonstrated that the nano-sheets show low cytotoxicity on the human cell line compared with the chemical nematicide. The r-GO was tested against the nematode during their life span and it was observed that the $r-G O$ is capable to reduce the nematode gall number and egg mass of $94 \%$ and $99 \%$, respectively. Moreover, the toxicity of the r-GO against the Juvenile (J2) root-knot nematode (Meloidogyne incognita) was also examined either in laboratory or under the greenhouse conditions. On the other hand, the treatment with the r-GO under greenhouse conditions showed higher mortality of the J2 of $98.5 \%$ compared with nematicidal treatment of $96 \%$ in a soil infested with $M$. incognita. Also, the same treatment was sufficient in inducting the growth of tomato plants: fresh weight of the shoot system increased with $30 \%$ and of the root system increased up to $285 \%$; dry weight of the shoot system increased with $128 \%$ and of the root system increased up to 480\%. r-GO has a high nematicidal activity and it is safe for human. The $r$-Go could be used as safe nematocide because it is safe, cheep, could be produced at large scale, and it is a good additive for the soil.

Keywords: Meloidogyne incognita, carbon nanostructure, reduced graphene oxide r-GO, cytotoxicity and nematicide.

Nematodes are microscopic roundworms that live in many habitats. At least 2500 species of plant-parasitic nematodes have been described, characterized by the presence of a stylet, which is used for penetration of host plant tissue. Most of them attack roots and underground parts of plants, but some are able to feed on leaves and flowers. Plant-parasitic nematodes are of great economic importance. How ever, because most of them live in the soil, they represent one of the most difficult pest problems to identify, demonstrate and control [1]. Their effects are commonly underestimated by farmers, agronomists and pest management consultants, but it has been estimated that some $10 \%$ of world crop production is lost as a result of plant nematode damage [2].

Management of soil-borne plant pathogens, including parasitic nematodes, is one of the greatest challenges facing modern agriculture worldwide [3-7]. The importance of soil-borne pathogens in modern agriculture systems is made especially clear by the current concern worldwide to find alternatives to methyl bromide for preplant treatment of soils used to produce certain high-value crops. Losses caused by plant parasitic nematodes are estimated about US $\$ 100$ billion annually [8].

The field of nanotechnology is one among the foremost important and active areas of research in modern science. Nanotechnology deals with the formulation of experimental processes for the synthesis of nanoparticles with different sizes and shapes [9]. The application of nanoparticles (usually ranging from 1 to $100 \mathrm{~nm}$ ) is a developing and interesting area of nanotechnology.

The interesting physical properties of graphene, which consists of two dimensional (2D) sheet of covalently bonded carbon atoms [10], have led to much excitement in recent years in material science and condensed-matter physics. There are potential applications of graphene for nanoelectronics. This is due to the excellent physical and chemical properties, and remarkable electronic properties of graphene which make it an ideal candidate for several applications [11].

The biological applications of graphene and the reduced graphene oxide r-GO remain unexplored and wide-open, how ever. There are several prerequisites for biological applications for a new study. First, rational functionalization chemistry is needed to impart graphene with aqueous solubility and biocompatibility. R-GO and its chemically converted derivatives form stable suspensions in pure water, but generally aggregate in salt or other biological solutions [12-16]. For that reasons this study aimed to examine the bioactivity of the reduced graphene oxide as control agent for nematode. The toxicity of the r-GO was examined to avoid any hazardous effect on the health of both plant and animal compared with the chemically synthesized nematocide.

\footnotetext{
*email:popa_amorin@yahoo.com; simonābungau@gmail.com Phone +40726776588
} 


\section{Experimental part}

\section{Material and methods}

Root-knot nematode, Meloidogyne incognita was obtained from the Nematology Research Laboratory, Department of Plant Pathology, Faculty of Agriculture, Alexandria University.

\section{Preparation of reduced graphene oxide r-GO}

Reduced graphene oxide r-GO was prepared as follows: $3.0 \mathrm{~g}$ of graphite flakes were added to a 9:1 mixture of concentrated $\mathrm{H}_{2} \mathrm{SO}_{4} / \mathrm{H}_{3} \mathrm{PO}_{4}(360: 40 \mathrm{~mL})$ in ice bath. Then $18 \mathrm{~g}$ of $\mathrm{KMnO}_{4}$ were added very slowly to the mixture and heated to $50^{\circ} \mathrm{C}$ and stirred for $12 \mathrm{~h}$. The mixture was cooled to room temperature and then poured onto ice $(400 \mathrm{~mL}$ deionized water with $3 \mathrm{~mL} 30 \% \mathrm{H}_{2} \mathrm{O}_{\text {) }}$. The obtained r-GO suspension was washed with $1: 10^{2} \mathrm{HCl}$ solution ( $5 \mathrm{~L}$ ) using filter paper and funnel. Then, the r-GO paste was collected from the filter paper and dried at $60^{\circ} \mathrm{C}$, until it solidified. The solid was dispersed into deionized water in static state for 2-3 $\mathrm{h}$ and then slightly stirred by glass bar. The suspension was filtered and then washed with a lot of deionized water for two days, until the $\mathrm{pH}$ was nearly 7.0. The r-GO powder was obtained by dehydration at $60^{\circ} \mathrm{C}$, for $6 \mathrm{~h}$, under vacuum and it was dispersed into water by ultra-sonication. The obtained brown dispersion was then subjected to $30 \mathrm{~min}$ of centrifugation at $4000 \mathrm{rpm}$, to remove any un-exfoliated $r-G O$.

\section{Characterization of $r-G O$}

The crystal structure was determined by XRD analysis performed on Shimadzu X-ray diffractometer, operated at $40 \mathrm{kV}$ and $30 \mathrm{~mA}$ with Cu Ka radiation. The morphologies of the prepared samples were investigated by Scanning Electron Microscopy (SEM, J EOL J SM 6360LA, J apan) and Transmission Electron Microscopy (TEM, JEOL JEM-2100 plus, Japan). Raman spectra of the samples were measured (using Bruker, Senterra, Germany). The physical properties of the synthesized r-GO, with different morphological structures, were investigated using different techniques. The morphological structure and the chemical compositions of the r-GO nano pow der were examined.

\section{Transmission Electron Microscopy (TEM)}

TEM is used to scan a finely focused electron beam across the surface of a specimen. The reflected signals are collected, and their intensities are displayed on a cathode-ray-tube screen by brightness modulation. As already indicated, the method allows specimen magnifications to $300,000 \mathrm{X}$, while maintaining a large depth of focus. The ease of sample scanning by scanning electron microscope (over large distances) are quite appealing, in that a large sample viewing area is first surveyed (at generally low magnification) to seek out particular areas of interest, followed by high magnification of those specific areas for subsequent detailed investigations. The TEM is also extensively employed for the generation of dimensional and spatial relationship details of structure elements.

\section{Determination of cytotoxicity effect of r-GO and Commercial nematicide using MTT assay}

Human peripheral blood mononuclear cells (PBMCs), human normal fetal lung cell line (Wi-38), and normal adult African green monkey kidney cell line (Vero) were used to investigate the toxicity of $\mathrm{n}-\mathrm{GO}$ and of the commercial nematicidal (Vydate ${ }^{\circledR} \mathrm{L}$ and Nemaphos $40 \%$ ), according to the method described by Mosmann [17]. PBMCs are the most available sources of human normal cells for investigating the toxicity of any compounds. Human PBMCs were isolated according to the Ficoll-Hypaque density gradient centrifugation method [18]. The heparinized blood was gradually added over an equal volume of the FicollHypaque solution (density $=1.077 \mathrm{~g} / \mathrm{mL}$ ) and centrifuged at $2000 \mathrm{rpm}$ for $30 \mathrm{~min}$. The PBMCs at buffy layer were collected, suspended in PBS and centrifuged for $5 \mathrm{~min}$ at $1650 \mathrm{rpm}$. Cells were resuspended in RPMI 1640 medium (Lonza, USA) containing 10\% fetal bovine serum (GIBCO, USA); then the viability was determined by staining of 50 $\mu \mathrm{L}$ of PBMCs with $0.5 \%$ trypan blue and counting on a hemocytometer.

Human Wi-38 and mammalian Vero cells were maintained in DMEM medium (Lonza, USA), containing $10 \%$ fetal bovine serum. These cell lines were subcultured for 2 weeks before assay using trypsin EDTA (Lonza, USA). Their viability and counting were detected by trypan blue stain and hemocytometer. Human PBMCs, Wi-38 and Vero were seeded in 96 well culture plates $10^{5}, 10^{4}$ and $10^{3}$ cells per well, respectively, and incubated at $37^{\circ} \mathrm{C}$ in $5 \% \mathrm{CO}_{2}$ incubator. After $24 \mathrm{~h}$, the cells were treated with the serial dilutions of graphene oxide and commercial nematicidal (Vydate ${ }^{\circledR} \mathrm{L}$ and Nemaphos 40\%) $(0,6.25,12.5,25,50$ and $100 \mu \mathrm{g} / \mathrm{mL}$ ). After $72 \mathrm{~h}$ of incubation in $5 \% \mathrm{CO}_{2}$ incubator, $20 \mu \mathrm{L}$ of MTT solution ( $5 \mathrm{mg} / \mathrm{mL}$ ) was added to each well and incubated at $37^{\circ} \mathrm{C}$ for $4 \mathrm{~h}$ in $5 \% \mathrm{CO}_{2}$ incubator. MTT (Sigma, USA) solution was removed after centrifugation at $2000 \mathrm{rpm}$ for $10 \mathrm{~min}$ and the insoluble blue formazan crystals trapped in cells were solubilized with $150 \mu \mathrm{L}$ of $100 \%$ DMSO at $37^{\circ} \mathrm{C}$ for $10 \mathrm{~min}$. The absorbance of each well was measured with a microplate reader (BMG Lab Tech, Germany), at $570 \mathrm{~nm}$.

Determination half maximal inhibitory concentration $\left(I C_{50}\right)$ and safe dose $\left(E C_{100}\right)$ values

The half maximal inhibitory concentration $\left(\mathrm{IC}_{50}\right)$ and safe dose $\left(E_{100}\right)$ values were determined using Graphpadlnstat soltware as the concentration of $\mathrm{r}-\mathrm{GO}$ and commercial nematicidal (Vydate ${ }^{\circledR} \mathrm{L}$ and Nemaphos $40 \%$ ) that caused $50 \%$ and $100 \%$ cell viability, respectively; used data were calculated from the equation of cell viability. Additionally, morphological changes of r-GO and commercial nematicidal (Vydate ${ }^{\circledR} \mathrm{L}$ and Nemaphos $40 \%$ ) treated normal human and mammalian cells were investigated in comparison with untreated control cells, using phase contrast microscope supplemented with digital camera (Olympus, Japan).

Analysis of the cytotoxicity effect of $r-G O$ and Vydate ${ }^{\circledR} \mathrm{L}$ using fluorescence phase contrast microscope

Human PBMCs and normal cell lines were treated with $6.25 \mu \mathrm{g} / \mathrm{mL}$ of each tested r-GO and commercial nematicidal product (Vydate ${ }^{\circledR} \mathrm{L}$ and Nemaphos $40 \%$ ). After incubation for $72 \mathrm{~h}$, the cells were stained with $100 \mathrm{\mu g} / \mathrm{mL}$ of double fluorescent nuclear dyes; ethidium bromide and acridine orange (Sigma, USA) and then investigated using fluorescence phase contrast microscope (Olympus, Japan).

\section{Statistical analysis}

All data obtained from laboratory bioassay and pots experiment were analyzed using analysis of variance (ANOVA). The significant differences among treatments were determined according to the least significant differences (LSD), at $p<0.05$ level of probability using CoStat software. 


\section{Results and discussions}

1-ReducedGraphene synthesis and characterization

Chemical oxidation is the best method for graphene oxide and the morphology of the synthesized reduced graphene nano oxide may be graphene oxide (GO) or graphene nanoplatelet [19]. Oxidized graphene could be used in different applications especially as nematicide [2022]. Some authors used the graphene oxide in nematode control and they succeeded to identify many of microRNA which plays an important role in biocontrol of such pests $[23,24]$.

\section{1-1-Using Scanning and Transmission Electron Microscopes}

The obtained materials were characterized using SEM TEM, and the results presented in figures 1 and 2 revealed that the r-GO appeared as nano-sheets. The size of the obtained nanoparticles ranged from 20 to $100 \mathrm{~nm}$.

\section{1-2-X-Ray Diffraction}

Data obtained by the XRD (presented in fig. 2) showed a broad diffraction peak observed at $2 \theta=24.38$, which indicated that the obtained material is graphene $r-G 0$. This result was previously confirmed by other studies $[25,26]$; moreover, it was also confirmed using Raman analysis.
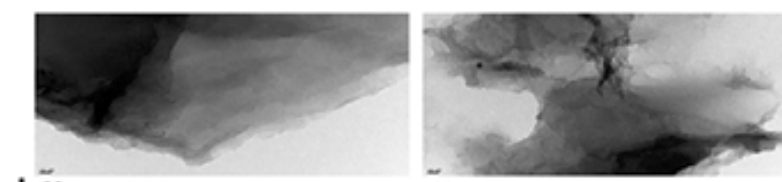

$120 \mathrm{~nm}$
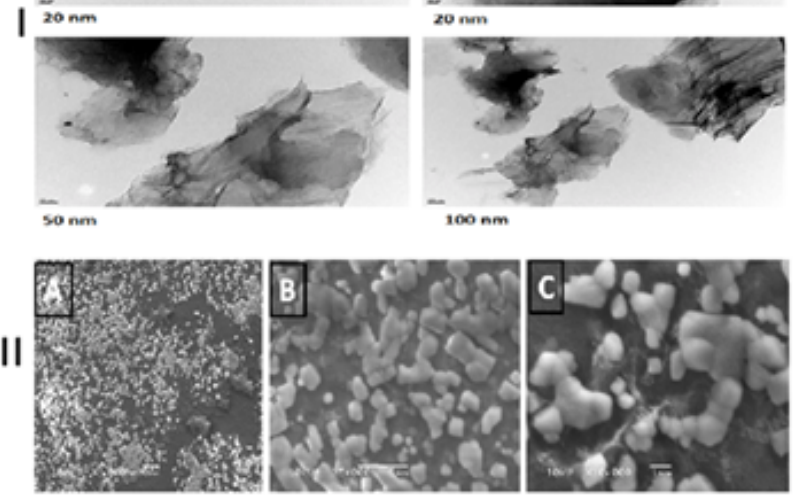

Fig.1. I: TEM micrograph of the obtained r-GO with different magnification, II: SEM micrograph of the obtained $r-G O$ under different magnifications

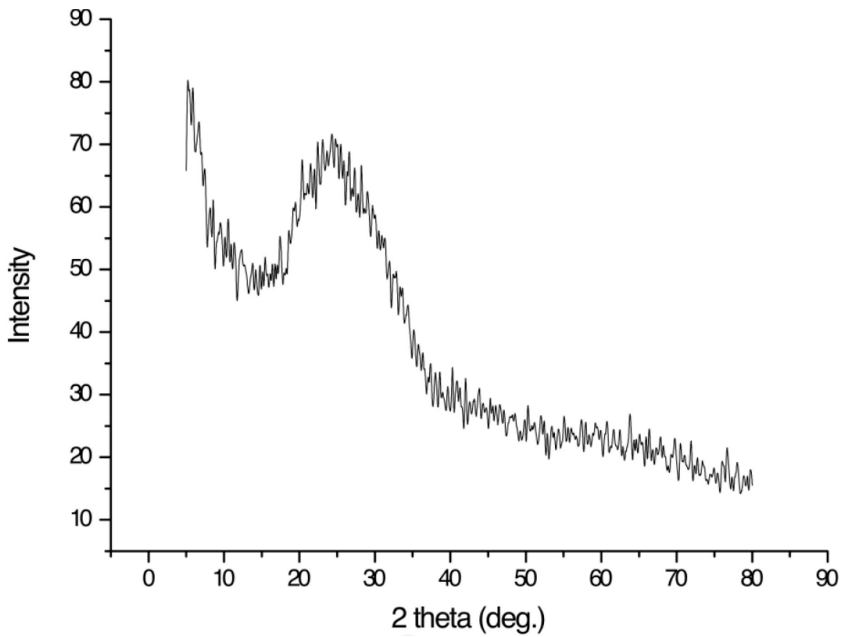

Fig.2. XRD pattern of the synthesized $r-G 0$

\section{1-3- Raman}

Data presented in figure 3 demonstrated that the obtained Raman spectra (which displayed the two main bands: $D$ band at $1350 \mathrm{~cm}^{-1}$ and the $\mathrm{G}$ band at $1590 \mathrm{~cm}^{-1}$ ) are the characteristics bands of graphene and/or the reduced graphene oxide [10]. This result confirmed the graphene structure obtained by XRD pattern.

\section{The cytotoxicity of the produced $r-G O$}

The largest $I C_{50}$ and $E C_{100}$ values indicate the highest safety of the two nematicides compared with the r-GO. Table (1) illustrates that three tested compounds had the highest $\mathrm{IC}_{50}(362.1,86.2$, and $203.9 \mu \mathrm{g} / \mathrm{mL})$ and $\mathrm{EC}_{100}$ (130, 52.1 , and $117.7 \mu \mathrm{g} / \mathrm{mL}$ ) doses against normal PBMCs, Wi38, and Vero cells. Moreover, there is no morphological differences were observed between untreated control cells in comparing with the treated cell lines. The $I C_{50}$ and IC of $r-G O$ were significantly $(p<0.001)$ higher than that of Vydate ${ }^{\circledR} L$, Nemaphos $40 \%$. Cytotoxicity of Vydate ${ }^{\circledR}$ L was intermediate between r-GO and Nemaphos $40 \%$. Nemaphos $40 \%$ is the most toxic compound on all tested normal human and mammalian cells (with the lowest IC and $\mathrm{EC}_{100}$ values, less than $17 \mu \mathrm{g} / \mathrm{mL}$ against PBMCs and 3 $\mu \mathrm{g} / \mathrm{mL}$ against Wi-38 and Vero cell lines).

Table 1

THE IC $_{50}$ AND EC $_{100}(\mu \mathrm{g} / \mathrm{mL})$ OF VYDATE ${ }^{\circledR}$ L, NEMAPHOS $40 \%$ AND r-GO AGAINST Wi-38, PBMCS AND VERO CELLS

\begin{tabular}{|c|c|c|c|c|c|c|}
\hline \multirow{2}{*}{ Nematicides } & \multicolumn{2}{|c|}{ Wi-38 cells } & \multicolumn{2}{c|}{ PBMCs } & \multicolumn{2}{c|}{ Ver0 cells } \\
\cline { 2 - 7 } & IC $_{50}$ & EC $_{100}$ & IC $_{50}$ & EC $_{100}$ & IC50 & EC100 \\
\hline Vydate & $49.78 \pm 8.4^{\circ}$ & $25.88 \pm 2.0^{\circ}$ & $126.27 \pm 5^{\circ}$ & $52.82 \pm 3.6^{\circ}$ & $57.83 \pm 2.2^{\circ}$ & $28.94 \pm 0.65^{\circ}$ \\
\hline Nemaphos $40 \%$ & $0.67 \pm 0.03^{\circ}$ & $0.144 \pm 0.09^{\circ}$ & $16.74 \pm 0.48^{\circ}$ & $5.43 \pm 0.57^{\circ}$ & $2.6 \pm 1.4^{\circ}$ & $0.131 \pm 0.00^{\circ}$ \\
\hline r-GO & $86.25 \pm 1.4^{\mathbf{a}}$ & $52.08 \pm 1.04^{\mathrm{a}}$ & $362.11 \pm 0.5^{\mathrm{a}}$ & $130 \pm 2.17^{\mathrm{a}}$ & $203.9 \pm 3.6^{\mathrm{a}}$ & $117.68 \pm 1.2^{\mathrm{a}}$ \\
\hline
\end{tabular}

*All values are expressed as mean \pm SEM. Different letters of the same column indicate significantly differences at $p=0.05$.

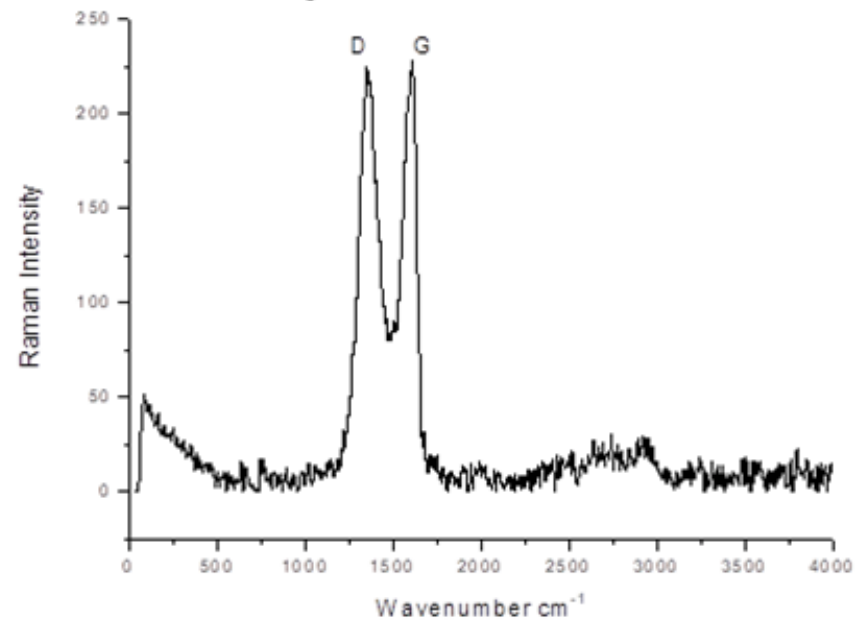

Fig.3. Raman spectra of the synthesized ( $r-G 0)$ 

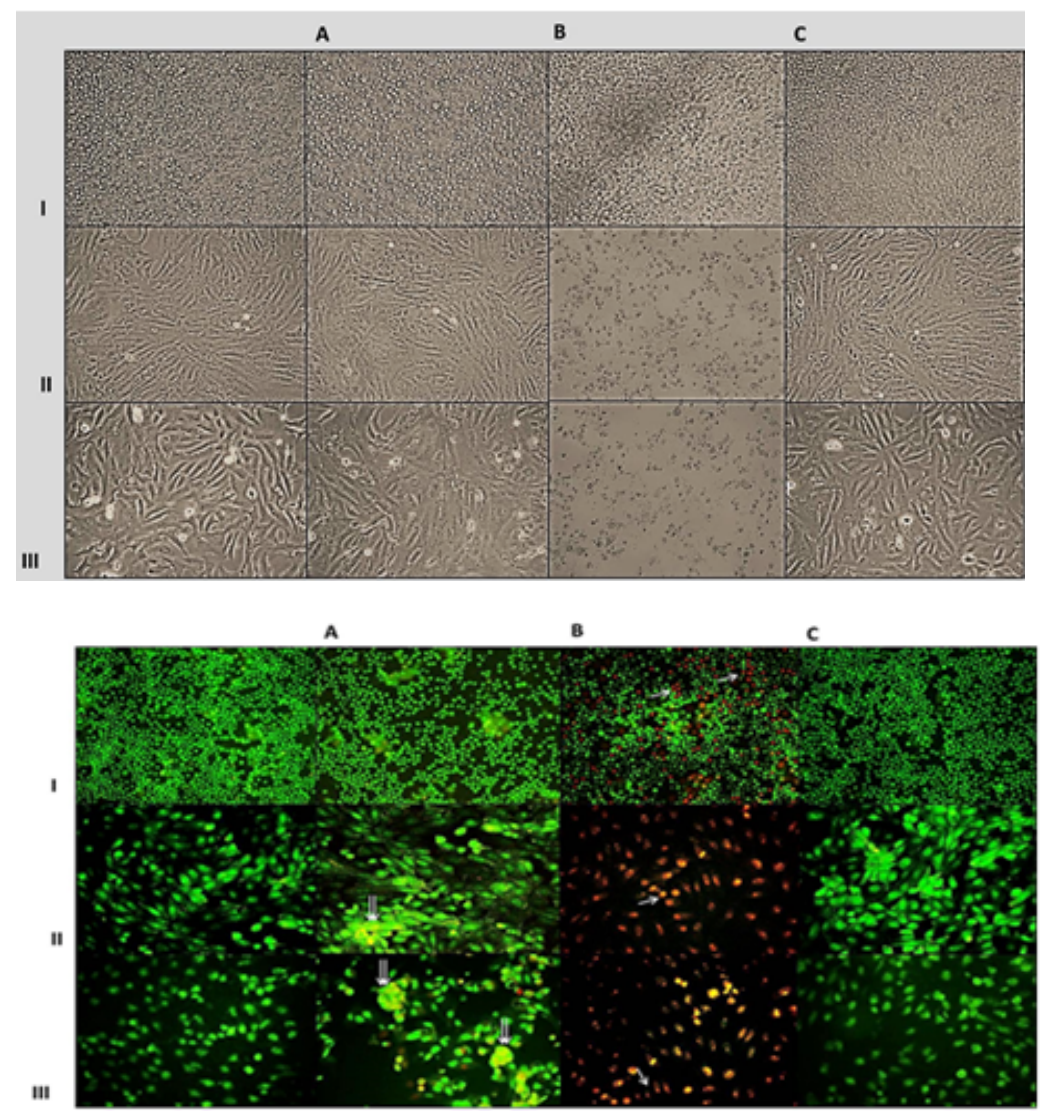

Fig.5. Morphological features of PBMCs (I), Wi-38 (II), and Vero (III) after exposure to the lowest concentration $(6.25 \mu \mathrm{g} / \mathrm{mL})$ of (A) Vydate ${ }^{\circledR}$ L, (B) Nemaphos $40 \%$, and (C) r-GO, using fluorescence microscope (Magnification $x$ 200). Normal cells emitted green color, early apoptotic cells exhibit a bright green to yellow (double arrow), while late apoptotic cells have bright orange to red nuclei (single arrow)

The highest cytotoxicity of Nemaphos $40 \%$ was confirmed by figure 4 (I, II and IIIB) that demonstrated severe alterations in normal shape of all investigated cells while r-GO and Vydate ${ }^{\circledR} \mathrm{L}$ treated cells showed normal morphology (fig. 4. I, II, IIIA and C). Moreover, nuclei of Nemaphos 40\% treated normal human cells exerted orange and red fluorescences when were stained with Ethidium Bromide-Acridine orange dyes that assured late stage of apoptosis was occurred (fig.5 I, II, and IIIB). Vydate ${ }^{\circledR} \mathrm{L}$ treated PBMCs exhibited green color while Vydate ${ }^{\circledR} \mathrm{L}$ treated Wi-38 and Vero cells emitted green with limited area of bright green or yellow fluorescence (fig.5I, II, and IIIA). r-GO treated human cells have green nuclei like that of untreated human cells. This indicates the highest safety of r-GO towards human cells compared to other two investigated nematicide (fig. $5 \mathrm{I}, \mathrm{II}$, and IIIC). On the contrary, Liao etal reported that r-GO has cytoxicity through oxidative induction, suppression of cell division which leads to the cell death [27]. Several studies postulated that r-GO has immunotoxicity $[21,28,29]$. Moreover, the cytotoxicity of the r-GO was examined in vivo either on rat or mice and it was observed that r-GO causes pulmonary and reproductive toxicity [22, 30-33]. Different reports on the toxicological studies on the environment and on the nematodes (Caenorhabditis elegans) as animal models and concluded that $\mathrm{r}-\mathrm{GO}$ has toxicity on the nematode [34-37].

Results presented in table 2 revealed that the nematode galls were controlled by the $r-G O$ and Vydate $L$ with percentage of 94 and 93 respectively, whereas the nematode egg mass was controlled in equal manner. On the other hand, reduction in the number of 2 was recorded as 67 and $80 \%$ with Vydate $L$ and $r-G 0$ respectively. Data presented in table 3 showed that there is an increase in shoot and root (dry and fresh) and in chlorophyll as well with percentage ranged from 20 to $285 \%$. Wu et al. [9] used different concentrations of $\mathrm{r}-\mathrm{GO}$ and they found that concentrations of 10-100 mg/L showed control activity against the J2. The same observation was reported by Yang et al. [20,22] that r-GO at the concentration of $100 \mathrm{mg} / \mathrm{L}$ reduced the lifespan of the larvae and inhibit their locomotion activity. The results obtained by Zhi et al. [28] confirm the findings in this study and also that obtained by Yang et al. $[20,22]$ that $r-G O$ is capable to control the nematode through inhibiting the ROS of its biological system. Other authors [38,39] confirm the results obtained in this study and they added that many regulatory genes of the treated nematode by r-GO could be affected and resulted in the death of the animal. Data represented in table 4 showed that the $\mathrm{J} 2$ mortality after 6 hrs with the

Table 2

NEMATICIDAL EFFECTS OF r-GO ON NUMBER OF NEMATODE GALLS (G), EGG MASSES (EM) OF TOMATO PLANTS INOCULATED WITH M. INCOGNITA (MI) AND DECREASE \% (D)

\begin{tabular}{|l|c|c|c|c|c|c|}
\hline \multirow{2}{*}{ Treatment } & \multicolumn{5}{|c|}{ Number } & \\
\cline { 2 - 7 } & G/plant & D \% & EM/plant & D \% & J/200 g soil & D \% \\
\hline Check & $55.3^{\mathrm{a}}$ & - & $100^{\circ}$ & - & $54.0^{\circ}$ & - \\
\hline Vydate $^{2} \mathrm{~L}$ & $4.0^{\circ}$ & 92.7 & $1.8^{\circ}$ & 98.2 & $10.7^{\circ}$ & 80 \\
\hline r-GO & $3.5^{\circ}$ & 93.7 & $1.5^{\circ}$ & 98.5 & $13.0^{\circ}$ & 76 \\
\hline
\end{tabular}

Data are means of 5 replicates; means with the same letter(s), in each column, are no significantly different at $(\mathrm{p} \leq 0.05)$. Check - plants inoculated with Meloidogyne incognita,

r-GO - reduced Graphene oxide 
Table 3

THE EFFICACY OF r-GO AND VYDATE L ${ }^{\circledR} S$ 24\% ON GROWTH PARAMETERS AND CHLOROPHYLL CONTENTS OF TOMATO PLANTS INFECTED WITH M. INCOGNITA (MI) AND INCREASE \% (I)

\begin{tabular}{|c|c|c|c|c|c|c|c|c|c|c|}
\hline \multirow{2}{*}{ Treatment } & \multicolumn{4}{|c|}{ Fresh weight (g) } & \multicolumn{4}{|c|}{ Dry weight (g) } & \multirow{2}{*}{$\begin{array}{l}\text { Chlorophyll } \\
\text { (U) }\end{array}$} & \multirow{2}{*}{ I } \\
\hline & Shoot & I & Root & I & Shoot & I & Root & I & & \\
\hline Check & $15.7^{\circ}$ & - & $5.945^{\circ}$ & - & $3.73^{\circ}$ & - & $1.55^{\circ}$ & - & $2.66^{\mathrm{d}}$ & - \\
\hline Vydate $^{2} \mathrm{~L}$ & $15.4^{68}$ & - & $8.0^{\circ}$ & - & $3.75^{\circ}$ & - & $1.95^{\circ}$ & - & $3.81^{\circ}$ & 43.2 \\
\hline r-GO & $20.4^{2}$ & 30.0 & $22.9^{3}$ & 285.0 & $8.49^{\circ}$ & 128.6 & $9.00^{2}$ & 480 & $4.99^{2}$ & 87.5 \\
\hline
\end{tabular}

Data are means of 5 replicates; means with the same letter(s), in each column, are no significantly different at ( $\mathrm{s} \leq 0.05)$. Check plants inoculated with Meloidogyne incognita, r-GO- reduced Graphene oxide.

Table 4

EVALUATION OF THE NEMATICIDAL EFFECTS OF REDUCED GRAPHENE OXIDE ON J 2 MORTALITY OF M. INCOGNITA AND REDUCTION \% (R) AFTER 6 AND $48 \mathrm{~h}$

\begin{tabular}{|c|c|c|c|c|c|c|c|c|}
\hline \multirow{3}{*}{ Type of the treatment } & \multicolumn{8}{|c|}{ Mortality (\%) after treatment } \\
\hline & \multicolumn{4}{|c|}{$6 \mathrm{hrs}$} & \multicolumn{4}{|c|}{$48 \mathrm{hrs}$} \\
\hline & $\mathrm{S}$ & $\bar{R}$ & $\mathrm{~S} / 2$ & $\mathrm{R}$ & $\mathrm{S}$ & $\bar{R}$ & $\mathrm{~S} / 2$ & $\mathrm{R}$ \\
\hline Water & $100^{\circ}$ & - & $100^{\mathrm{a}}$ & - & $230^{\circ}=$ & - & $230^{\mathrm{a}}$ & - \\
\hline Vydate $^{2} \mathrm{~L}$ & $3.0^{\mathrm{C}}$ & 96.2 & $3.0^{60}$ & 96.2 & $8.9^{\circ}$ & 96.1 & $10.0^{\circ}$ & 95.6 \\
\hline $\mathrm{r}-\mathrm{GO}$ & $18.9^{6}$ & 89.5 & $8.4^{\circ}$ & 89.5 & $9.8^{6}$ & 95.73 & $9.8^{6}$ & 95.7 \\
\hline
\end{tabular}

Data are means of 5 replicates; means with the same letter(s), in each column, are not significantly different at (P $\leq 0.05)$.

* - Number of alive juveniles in the negative control (DW). S - Standard concentration (100\%) of r-GO, S/2 - Mortality with $50 \%$ concentration of $\mathrm{r}-\mathrm{GO}$.

Vydate $^{\circledR} \mathrm{L}$ was of $96 \%$ followed by a decrease r-G0 $89 \%$, respectively.

On the other hand, the 2 mortality with $50 \%$ Vydate ${ }^{\circledR} \mathrm{L}$. (96.2\%) decreased, followed by $50 \%$ r-G0 $89.5 \%$ decrease. Moreover, it was observed that there is no difference in the results obtained either r-GO or Vydate ${ }^{\circledR} \mathrm{L}$. Some authors used the biosynthesized nanosilver as nematocide and they found that the green synthesis nano metal could be a safe substitution to the chemical pesticides $[40,41]$. Different studies reported that r-GO has cytotoxicity against the nematode and they postulated that the r-GO kill the nematode through activating the oxidative stress in the animal $[30,41,42]$. We assume that the $r-G 0$ has cell specificity, because it has no toxicity on the human cells, but it has high toxicity on the nematode cells.

\section{Conclusions}

Reduced graphene oxide sheets could be used as nematocide with efficacy more than $90 \%$. In addition, it has no toxicity on human cells which recommend this product as a new pesticide without hazards on human being. Also, it is the main constituent of soil composition, so it has no harmful effects on the soil chemistry.

\section{References}

1.STIRLING, G.R., NICOL, J.M., REAY, F. Rural Industries Research and Development Corporation Publication, Advisory services for nematodes pests - operational guide 1998; 99/41.

2.W HITEHEAD, A.G. Wallingford, UK: CAB International; Plant nematode control 1998.

3.BUNGAU, S., TIT, D.M., FODOR, K., CIOCA, G., AGOP, M., IOVAN, C., NISTOR CSEPPENTO, D.C., BUMBU, A., BUSTEA, C., Sustainability, 10 nr. 8, 2018, 2788. doi:10.3390/su10082788

4.GITEA, M.A., BUNGAU, S., GITEA, D., PURZA, L., NEMETH, S., SAMUEL, A.D., BADEA, G., TIT, D.M., Rev. Chim.(Bucharest), 69, no. 6, 2018, p. 1303.

5.SAMUEL, A.D., BREJEA, R., DOMUTA, C., BUNGAU, S., CENUSA, N., TIT, D.M., J. Environ. Prot. Ecol., 18, nr. 3, 2017, p. 871.

6.SAMUEL, A.D., BUNGAU, S., TIT, D.M., MELINTE, (FRUNZULICA), C.E., PURZA, L., BADEA, G.E., Rev. Chim.(Bucharest), 69, no. 10, 2018, p. 2608.

7.SAMUEL, A.D., TIT, D.M., MELINTE (FRUNZULICA), C.E., IOVAN, C., PURZA L., GITEA, M., BUNGAU, S., Rev. Chim.(Bucharest), 68, no. 10, 2017, p. 2243.
8.FLEMING, T.R., MAULE, A.G., FLEMING, C.C., J. Nematol., 49, nr. 4, 2017, p.462

9.WU, Q., ZHAO, Y., ZHAO, G.,WANG, D. Nanomedicine: NBM, 10, 2014, p. 1401.

10.BITTOLO BON, S., VALENTINI, L, KENNY, J.M., PEPONI, L., VERDEJ O, R., LOPEZ-MANCHADO, M.A., Phys. Status Solidi A., 207, nr. 11, 2010, p. 2461.

11.KRISHNAMOORTHY, K., KIM, S.J., J. Ind. Eng. Chem., 32, 2015, p. 39. doi doi: 10.1016/j.jiec.2015.09.012

12.BALINT, R., NECHIFOR, G., AJ MONE-MARSAN, F., Environ. Sci.Processes \& Impacts, 16, nr. 2, 2014, p. 211.

13.BALINT, R., ORBECI, C., NECHIFOR, G., PLESCA, M., AJMONEMARSAN, F., Rev. Chim.(Bucharest), 64, no. 11, 2013, p. 1218.

14.DIACONU, I., GIRDEA, R., CRISTEA, C., NECHIFOR, G., RUSE, E., TOTU, E.E., Rom. Biotech. Lett., 15, nr. 6, 2010, p. 5702.

15.ORBECl, C., NECHIFOR, G., STANESCU, R., Environ. Eng. Manag. J., 13, nr. 9, 2014, p. 2153.

16.HODISAN, S., BADEA, G.E., BUNGAU, S., SEBESAN, M., MELINTE (FRUNZULICA) C.E., POPA, M., TIT, D.M., Rev. Chim.(Bucharest), 69, no. 9, 2018, p. 2318.

17.MOSMANN, T. J. Immunol. Methods, 65, nr. 1, 1983, p. 55.

18.BOYUM, A. SCAND. J. CLIN. LAB. INVEST. SUPPL., 21, 1968, P. 77.

19.PEI, S., CHENG, H.-M., Carbon, 50, nr. 9, 2012, p. 3210.

20.YANG, R., REN, M., RUI, Q., WANG, D., Sci. Rep., 6, 2013, 32214. doi: 10.1038/srep32214.

21.CHANG, Y., YANG, S.H., LIU, J., DONG, E., WANG, Y., CAO, A., LIU, Y., WANG, H. Toxicol. Lett., 200, 2011, p. 201.

22.YANG, K., LI, Y., TAN, X., PENG, R., LIU, Z. Small, 9, 2013, p. 1492. 23.WU, Q.L., ZHAO, Y.L., FANG, J.P., WANG, D.Y., Nanoscale, 6, 2014, p. 5894.

24.WU, Q., ZHAO, Y., ZHAO, G.,WANG, D. Nanomedicine: NBM, 10, 2014, p. 1401.

25.DONG, Y., LIN, J., CHEN, Y., FU, F., CHI, Y., CHEN G. Nanoscale, 6, 2014, p. 7410.

26.DONG, Y.Q., LI, G.L., ZHOU, N.N., WANG, R.X., CHI, Y.W., CHEN, G.N., Anal. Chem., 84, 2012, p. 8378.

27.LIAO, K., LIN, Y., MACOSKO, C.W., HAYNES, C.L. ACS Appl. Mater. Interfaces, 3, 2011, p. 2607.

28.LI, Y., WU, Q., ZHAO, Y., BAI, Y., CHEN, P., XIA, T., WANG, D. ACS Nano, 8, 2014, p. 2100.

29.ZHI, L., REN, M., QU, M., ZHANG, H., WANG, D., Sci. Rep., 6, 2016, 39261.

30.ZHANG, W., WANG, C., LI, Z., LU, Z., LI, Y., YIN, J., ZHOU, Y., GAO, X., Carbon, 49, nr. 3, 2010, p. 986. 
31.ZHANG, W., WANG, C., LI, Z., LU, Z., LI, Y., YIN, J., ZHOU, Y., GAO, X, FANG, Y., ZHAO, Y., Adv. Mater., 24, 2014, p. 5391.

32.LI, B., YANG, J., HUANG, Q, ZHANG, Y., PENG, C., ZHANG, Y., HE, Y., SHI, J., LI, W., HU, J., FAN, C., NPG Asia Mater, 5, 2013, e44.

33.LIANG, S., XU, S., ZHANG, D., HE, J., CHU, M., Biomaterials, 9, 2015, p. 92.

34.LEUNG, M.C., WILLIAMS, P.L., BENEDETTO, A., AU, C., HELMCKE, K.J., ASCHNER, M., MEYER, J.N., Toxicol. Sci., 106, 2008, p. 5.

35.ZHAO, Y.-L., WU, Q.-L., LI, Y.-P., WANG, D.-Y., RSC Adv., 3, 2013, p. 5741.

36.TEJ EDA-BENITEZ, L. , OLIVERO-VERBEL, J., Rev. Environ. Contam. Toxicol., 237, 2016, p. 1.

37.WANG, D.Y., Toxicol. Res., 5, 2016, p. 1003.
38.XIAO, G., ZHI, L., DING, X., RUI, Q., WANG, D., RSC Adv., 7, 2017, p. 52694.

39.ZHI, X., FANG, H., BAO, C., SHEN, G., ZHANG, J., WANG, K., GUO, S., WAN, T., CUI, D., Biomaterials, 34, nr. 21, 2013, p. 5254.

40.AGARWAL, S., SADEGHI, N., TYAGI, I., GUPTA, V.K., FAKHRI, A.J ., Colloid Interface Sci., 478, 2014, p. 430.

41.ABBASSY, M.A., ABDEL-RASOUL, M.A., NASSAR, A.M.K., SOLIMAN, B.S.M., Arch. Phytopathol. Plant Protection, 2017, 50, nr. 17-18, p. 909. doi:10.1080/03235408.2017.1405608.

42.WU, Q., YIN, L., LI, X., TANG, M., ZHANG, T., WANG, D., Nanoscale, 5, 2013, p. 9934

Manuscript received: 26.11 .2018 